\title{
Religion and the Rwandan Genocide
}

Within a period of three months in 1994, between 800,000 and 1,000,000 people were killed (men, women, children and elderly people) in the African country of Rwanda. Rwandan nationals were killed by Rwandan nationals. In many cases the machete, one of the most ordinary instruments of every household, was used as a weapon. Sometimes, people who had sought refuge in an overcrowded school or church were slaughtered by grenades thrown by militias. Most of the victims belonged to the Tutsi minority, who, it is estimated, represented 15 per cent of the population. The perpetrators were Hutu, the segment of the population that is estimated to have represented more than 80 per cent of the population. Among the very tiny minority of the Twa, there were both victims and perpetrators.

During the period of the genocide, four out of five members of the population were members of a Christian church. ${ }^{1}$ The role of religion in this brutal killing can be treated from different angles (van 't Spijker 1997). In the years of political change and tensions preceding the genocide, many leaders of the most important churches had developed systematic and skilful initiatives for mediating between the different political parties and powers, in many cases not without success. Christian laymen have been very active in human rights organizations, challenging political leaders, and organizing marches for peace at the beginning of 1994 supported by thousands of participants in the most important cities (Gatwa 2005: 181218). The Christian religion has been important in prompting many people to risk their lives by offering protection to Tutsis who were threatened, and several people have died as martyrs (Rutayisire 1996). Religion is of enormous importance to all the people who have had to come to terms with the loss of relatives in the violent political turmoil before, during and after

1 In 1994, 80 per cent of the population was Christian. Roman Catholics formed 60 per cent of the population, and Protestants 23 per cent, of whom the majority were Pentecostals, whereas the older churches were Presbyterians (established in 1907), Seventh-Day Adventists (1918), Episcopalian (Anglican) Church (1921), Baptists (1937), and Free Methodists (1942). 
the genocide, with the result that churches and mosques are even more frequently visited than before the violent period in Rwanda's history. After the genocide, many Christian initiatives were developed for the care of widows and orphans, out of pure compassion and with a view to reconciliation, initiatives in which the activities of individuals are more impressive than those of the official churches. Religion also plays a role when the perpetrators of genocide confess their guilt, although the question should be asked if the pressure on the part of the government is of more overriding importance than the persuasion used by religious ministers and others who preach the Gospel to the detainees (Molenaar 2005: 53-8).

Nevertheless, one of the most urgent questions - formulated as an accusation by the present political regime in Rwanda - is whether religion and the influence of the churches and church leaders have, in fact, fuelled the genocide, or even was Christian missionary activity the ultimate cause of the genocide?

Effectively, in the broader circles of the present regime that articulate public opinion, it is argued that the presence of Christianity, more precisely the activities of the Roman Catholic Church, has not only contributed to the possibility of the genocide, but has been at the root of the political constellation that led to the genocide, and that during the genocide, Church leaders were actively involved in it. In many documents, it is argued that the Rwandan genocide would never have taken place, if Christian missions, particularly those of the Roman Catholic Church, had not been established in Rwanda.

Related to this is the question of how the religious change after the genocide is to be interpreted, since in fact, after 1994, many new Christian communities have been founded, and a striking growth of Islam may be noticed.

In order to discuss this set of problems, we first have to highlight some of the most important data concerning the political developments that preceded the genocide. Therefore, we have to explore more extensively the way in which Christianity, and more precisely the Roman Catholic Church, was closely connected to the emergence of the Rwandan nation, and how the relations between Hutu and Tutsi have developed in the course of the history of Rwanda. More extensive analyses have been made by Filip Reyntjens (1994), Gérard Prunier (1995), Jean-Claude Willame (1995), and C. M. Overdulve (1997). 


\section{Some Facts about the Genocide}

The event that triggered the beginning of the genocide was the shooting down of the aeroplane of Major-General Juvénal Habyarimana, the President of Rwanda since 1973, which caused his death on Wednesday April 6th 1994, at 20.23 hours.

Immediately after the death of the president, the prime minister, Agatha Uwiligiyimana, was killed, and a new government was formed which encouraged the killing of all Tutsi in the country.

Fierce fighting followed between the Rwandan Army and Tutsi rebels who had already invaded the country in 1990, and had since then occupied a part of the country. The new government and the army were finally driven into Congo (Zaire), and in July, when the Rwandese Patriotic Front (RPF) had gained control of the country, an RPF-dominated government was formed. In the period between April and July, more than 800,000 Tutsi, and an important number of 'moderate Hutu' were slaughtered.

The genocide was the culmination point of a war that had started in October 1990 with the invasion by the army of the Rwandese Patriotic Front, consisting mainly of second generation refugees who had fled the country in 1959 and 1973, and whose leaders had formed the core of the Ugandan Army that brought Yoweri Museveni to power as president in 1986.

During the war that followed the invasion of 1990, the rebel army, as it was called, occupied a considerable part of the country, and the territory it controlled continued to increase.

As the invasion of the RPF in 1990 did not result in an uprising of the Tutsi in the country, the term civil war would be misleading. But after 1990, the tensions between Hutu and Tutsi in the country grew considerably, and became even more acute when, in neighbouring Burundi in October 1993, the democratically chosen Hutu president, Melchior Ndadaye, was killed by the Tutsi-dominated army in that country.

Under international pressure, peace talks in Arusha led to an agreement that brought the RPF in a favourable position. Hutu extremists rejected the peace agreement and prevented its implementation. The attack on the presidential aircraft followed a possible breakthrough in the negotiations between the different parties that were promoted by Tanzania and other neighbouring countries. 


\section{Return of Rwandan Refugees Who Fled the Country in 1959 and 1973}

The invaders from Uganda entered the country by force as a result of a sad history of relations between Hutu and Tutsi in the past. They were the children of a generation of Tutsi who had fled the country following the bloody riots in 1959 and 1973.

Especially in 1959, there had been a social uprising, or social revolution by Hutu against the ruling Tutsi who had acted as masters of the country during the colonial period.

Rwanda had been under colonial leadership from about 1898 to 1961.

During the period 1898-1916, Rwanda was ruled by the Germans. They did not establish a strong colonial regime, but imposed their rule on the existing political system, consisting of a king with absolute and divine power at the top of a complicated political hierarchy in which power was placed in the hands of chiefs and army officers who for the most part belonged to a particular Tutsi clan or who had good relations with it.

A much more decisive role was played by the Belgians, during their period of power, 1916-61, as the mandatary of the League of Nations.

The Belgians reorganised the political system, and gave all the authority to newly appointed chiefs, who had to belong to the Tutsi class. This brought many Tutsi into powerful positions, and for a long period, particularly Tutsi were given access to secondary school education, and thus access to public positions, whereas Hutu were denied these.

During Belgian rule, the influence of the Roman Catholic Church was important. In fact Roman Catholic missionaries were seen as experts in the field of the complicated social relations of the Rwandan population. Roman Catholic missionaries thus promoted Tutsi rule, since according to the leading clergy, Tutsi 'were born to rule', being excellent in political leadership.

After the Second World War, the Catholic Church adopted another attitude towards the division of power in the nation. A new generation of missionary priests, influenced by social democratic ideas, promoted the development and well-being of the Hutu, who formed the majority of the population, but were oppressed by Tutsi leadership who had been given that position by the colonial regime.

When the call for independence spread throughout Africa, the Roman Catholic Church assisted the Hutu in claiming their political rights by promoting their political and social organisation. This resulted in a general uprising in 1959, and ultimately in the political independence of Rwanda as a nation under Hutu rule in 1961. 
In the years following independence, Rwanda was organised on the basis of proportional representation, which meant that Tutsi, representing 15 per cent of the population, were given only 15 per cent of the places in secondary and higher education and as civil servants. However they were denied important positions in the national army. This arrangement required a complicated system of civil administration in which the 'racial adherence' of each civilian was registered.

A bloodless military coup in 1973 gave power to Juvénal Habyarimana, who, in fact, considered Hutu and Tutsi to be different ethnic groups, without stressing their racial roots, since he considered Hutu and Tutsi in the first place to be Banyarwanda. He allowed Tutsi to share political power, but still excluded them from having any power in the army.

An important minority of the Tutsi started living as refugees, often in camps, in neighbouring countries. Several were given the opportunity to follow higher education. In Kenya as in Zaire many Tutsi were successful in business. In Uganda, Tutsi refugees, as was already mentioned, were finally accepted into the higher ranks of the military.

By the end of the nineties, many Rwandan refugees in Uganda were given important positions in the state, and President Museveni was willing to give them Ugandan citizenship on the basis of ten-years residence in the country. But at the end of the nineties, a crisis in Uganda led these rights being revoked, and as a consequence, the position of Rwandans in Uganda was questioned.

\section{The Relations between Hutu and Tutsi in the Colonial Period}

This roughly sketched historical background makes it clear that the relationship between Hutu and Tutsi is closely related to political developments in Rwanda in the past, especially in the twentieth century, the period of the colonization of Africa, in which particularly in Rwanda, Roman Catholic missionary activity played an important and decisive role.

There are in fact two main approaches to this colonial and missionary past that have to be mentioned, and by analysing these, we can see the ways in which Hutu and Tutsi identities have been defined. 


\section{Two Views on Rwandan History}

The majority of Hutu claim that there has been a growing antagonism down the centuries between the Hutu peasant majority and the Tutsi noble minority who possessed cattle. In the nineteenth century, the Tutsi king, Kigeri IV Rwabugiri (1867-95), worked out a political system in which Hutu vassals were in the service of the Tutsi, and effectively had no political rights. The German colonial regime cooperated with the Tutsi powers and did not make any significant changes in the system. The Belgian regime initially strongly promoted Tutsi domination, but changed this policy after World War II, when, encouraged by the influential Roman Catholic Church, it began to support the political rights of the Hutu majority.

Until the genocide, this was in general the view of Rwandan history that was presented. This view is expressed, for instance, by Roger Heremans (1993) and C. M. Overdulve (1997).

The interpretation of history by the present Tutsi-dominated government is different. According to this interpretation, Tutsi and Hutu lived in peace and harmony in Rwanda until the arrival of the European colonial powers. The social division of the population was interpreted by Europeans as being based on racial differences between Hutu and Tutsi, thus introducing fundamental discord between the two that had never existed before. The Belgian regime emphasized the excellence of the so-called Tutsi race even more than their German predecessors, and took them into service in order to oppress the Hutu.

However, before leaving the scene in 1962, the Belgians gave all political power to the Hutu. This, in fact, gave the Belgians the means to continue to influence the politics of the country. The Hutu could only maintain their position by systematically killing those Tutsi who claimed their political rights, and by prohibiting the return of the Tutsi refugees who had left the country during the riots of 1959-62 and in 1973. In order to put an end to this injustice, the Tutsi refugees organised themselves into the Rwandese Patriotic Front, they raised an army and started a struggle for liberation. This struggle is seen as the last anti-colonial war in Africa because the Hutu regime that came to power after independence continued to construct a society based on the racial divisions that had been introduced by the colonial powers in the twentieth century.

The racist interpretation of Rwandan society is seen as the most fundamental cause of the genocide. It was the Roman Catholic Church that had promoted these ideas and, through its quasi-monopoly of the educational system, it had exposed the population to these ideas, which were then in- 
ternalised during the course of the century. For this reason, the Catholic Church is ultimately responsible for the genocide. This view is held by Paul Kagame (2002).

The existence of these two opposing views of Rwanda's past is part of the problem, and is related to the upsurge of genocide. Both war and the genocide have created sorrow, mistrust and hatred, which together have blocked any open public debate about this ambiguous nature of Rwandan history.

\section{The Concept of Colonizers and Missionaries of Hutu and Tutsi Identity}

The missionaries who have been active in Rwanda, the Roman Catholics from 1900 and the Protestants from 1907 onwards, have followed the concepts of race developed by Western social sciences in the course of the nineteenth century. With reference to a famous study by Edith Sanders, we may state that the word 'race' was a favourite term in the language of the Enlightenment (Sanders 1969). Immanuel Kant considered the word race to be 'an important acquisition of human thinking'.

The presupposition was that the European race was to be considered superior to the rest of humankind. This may be illustrated by the way the scientists who accompanied Napoleon's army during its conquest of Egypt, concluded that such a rich culture, which had existed before the development of European culture, could not have been the creation of Negroes, who were descendents of the accursed Ham. The discovery of a certain linguistic relationship between Arabic and certain expressions used by Ethiopians and Nubians led to the conclusion that these particular peoples could not be Negroes, but must have been colonisers who had their origin in the Middle East.

This led to a revision of the Hamitic theory: it was not Ham and his descendents who were cursed, but rather Canaan, his son. Now the name Hamites became a name of honour: anything of value found in Africa was considered to have been introduced by the Hamites, imported into Africa.

These theories have served as a frame of reference for those who explored Africa, and finally they have become the basis of a classification of the peoples encountered there, including those of Rwanda.

In general, ethnographers of the nineteenth century spoke of Hamitic pastoralists who in the course of time must have arrived in the heart of Africa. Through their natural, racial superiority, these pastoralists were considered to have conquered the sedentary Bantu peoples. 
The explorers of Rwanda used the same ethnological framework, as may be demonstrated by a quotation from the book Caput Nili, in which the German anthropologist Richard Kandt, who spent a long time in Rwanda in the last years of the nineteenth century, gives an account of his experiences. In the same words as Count von Goetzen, who had paid a visit to the Rwandese court in 1898, he was delighted to discover a 'densely populated country, an agreeable climate, and a well organised kingdom in which the Hutu are totally subordinate to the Tutsi minority'. Waiting in Nyanza for his first encounter with the Rwandan king, Mwami Yuhi V Musinga, on June 14th, 1898, he notes, thinking about the miraculous kingdom he has come to visit:

Graf Goetzen war es, der uns die erste sichere Kunde von diesem Lande brachte, dessen Grenze selbst die Araber auf ihren Sklavenjagden gescheut hatten. ... Er fand ein ungeheures Grasland, das von Ost nach West allmählich von 1500 bis 2500 Meteransteigt, reich an Gewässern und mit herrrlichem Klima; er fand in ihm nicht, wie inden übrigen Teilen der Kolonie, eine spärliche, sondern eine nach Hunderttausenden zählende Bevölkerung von Bantunegern, die sich Wahutu nannten; er fand dies Volk in knechtischer Abhängikeit von den Watussi, einer fremden semitischen oder hamitischen Adelskaste, deren Vorfahren aus den Gallaländern südlich Abessiniens kommnend, das ganze Zwischenseengebiet sich uinterworfen hatten; er fand das Land eingeteilt in Provinzen und Distrikte, die unter der aussaugenden Verwaltung der Watussi standen, deren riesige, bis über zwei Meter hohe Gestalten ihn an die Welt der Märchen und Sagen erinnerten, und an ihrer Spitze einen König, der im Lande ruhelos umherziehend, bald hier, bald dort seine Residenzen erbaute. (Kandt 1919: 1-2.)

On the basis of these observations, the missionaries, who first arrived in 1900, formed their ideas about the Rwandan population, developed their missionary strategy, and inspired the political colonial regime that created the administrative structures in the twentieth century. A quotation from the work of one of the missionaries, A. Pagès, a member of the White Fathers, is highly illustrative:

Monophysites à leur départ d'Abyssinie, les hamites ont peut-être peu à peu oublié, au cours de leur longue exode, la croyance chrétienne et adopté les pratiques et les superstitions des peuples au milieu desquels ils ont vécu' (Pagès 1933: 8). 
This relationship between the different segments of the Rwandan population, and its racial interpretation, have been the point of departure for the political regimes of the twentieth century when creating the social and political institutions of the nation.

This interpretation of Rwandan society by explorers and missionaries corresponds remarkably well to the popular local mythology found by missionaries, in which the Tutsi are pictured as excellent, clever, and brilliant, the Hutu as lazy and inattentive, and the Twa as the official jokers. In the myths and legends, the first divine king of Rwanda, Kigwa, is said to have three sons: Tutsi, Hutu and Twa. Kigwa tested their skills and conduct, and gave them, accordingly, their special places in society: Tutsi became the leader, Hutu the worker under the leadership of Tutsi, and Twa became the marginalized person with a clownish role at the royal court. Several missionaries such as the Roman Catholic, Father Loupias and the Lutheran, Ernst Johanssen, have recorded myths that circulated at the beginning of the twentieth century concerning the origin of the different segments of the population in Rwanda and their relationships (Loupias 1908: 1-13; Johanssen 1912: 70-5).

These myths should be seen as legitimising the oppressive rule and the stringent political organisation of two kings in the nineteenth century, Mutara II Rwogera (1845-67) and Kigeri IV Rwabugiru (1867-95). The American political scientist René Lemarchand observes that: 'Hamitic theories showed an uncanny fit with the mythologies of traditional Rwanda; once incorporated into the work of historiographers it became increasingly difficult to tell them apart' (Lemarchand 1999: 8).

In fact, this view has been the point of departure for successive political regimes during the twentieth century when they created the social and political institutions of the nation.

The Hutu majority were seen as native Rwandans, and the Tutsi minority were seen as non natives, and thus as intruders. This thinking has also been decisive in identifying Hutu and Tutsi over the course of time. In the 1950s, extremist political parties, both Hutu and Tutsi, have explicitly referred to this historical 'origin' of Rwandan society. ${ }^{2}$

2 The Hutu manifesto, a political statement by Hutu intellectuals, appealing to the self-confidence of the Hutu population on the eve of political independence, signed on March 24, 1957, without referring to the historical origin of Hutu and Tutsi, speaks of a full century of Tutsi domination, followed by 56 years of European dominance. A reply to this manifesto was given in a declaration signed on May 17, 1958, by a number of dignitaries of the Royal Court, the Bagaragu bakuru b'ibwami 
It should be mentioned that the racist interpretation of the identity and origin of Hutu and Tutsi has left some crucial phenomena in Rwandan society unexplained:

- In the popular and in the official memory of Rwanda no mention is made of a systematic migration of Tutsi into the country.

- All Rwandans belong to one of about eighteen clans. Almost all clans are constituted of Hutu and Tutsi (d'Hertefelt 1971: 9-21).

- Tutsi and Hutu have never lived as separate cultural communities. They speak the same language, they have long practised the same traditional religion, and live in the same territory.

- There are certain examples, albeit rare ones, of a change of identity: a Hutu, who had accumulated wealth in the form of cattle, could rise in the socio-economic hierarchy and become Tutsi, whereas in certain cases, Tutsi could lose their status and become Hutu.

Because the use of racial theories says more about the feeling of superiority of those who invented them than it does about the African peoples who have been classified, historians have long ago abandoned thinking in terms of race. ${ }^{3}$

\section{Hutu and Tutsi as Political Identities}

The question arises as to what other meaning should be given to the words Hutu and Tutsi if these are not racial terms. Here I would like to refer to the Ugandan sociologist Mahmood Mamdani, who proposes seeing the words Hutu and Tutsi as referring to political identities that have been subject to a change in meaning over the course of time.

After critically examining the different efforts made by several historians, he concludes that it is fruitless to search distant history for the origins of Hutu and Tutsi. 'Hutu and Tutsi have changed as political identities

(who certainly represented only a minority of the Tutsi), stating that 'the relationships between us (Batutsi) and them (Bahutu) have always been based on servitude; there is thus between us no foundation for fraternity whatsoever.' For the complete text see, Overdulve 1997: 97-118.

3 George P. Murdock, quoted by Joseph Ki-Zerbo (1978: 307), wrote in 1964: 'The Hamitic hypothesis must be classified in the museum of prejudices invented in the colonial period'. 
along with the state that has enforced these identities' (Mamdani 2001: 34).

The term Hutu only started to make sense when people were subordinated to a state ruled by Tutsi, who in the distant past may have represented an ethnic identity.

Tutsi may have existed as an ethnic identity before the establishment of the state of Rwanda. These Tutsi created a kind of state, whose origins, on the basis oral history, may go back the fourteenth or fifteenth century, and in course of time they conquered people who were called Hutu, a word that means servant in several parts of Africa. These servants, may have belonged to different ethnic groups, but as people who were subjected to the emerging Rwandan state, they were called Hutu.

While we may be able to speak of Tutsi as an ethnic identity preceding the formation of the state of Rwanda, we certainly cannot speak of Hutu with the same historical depth. For as a political identity, Hutu was constructed as a consequence of the formation and expansion of the state of Rwanda. If subject populations only came to be defined as Hutu after being incorporated into Rwanda state structures, we cannot speak of these as Hutu before that incorporation. (Mamdani 2001: 73.)

With the formal mechanisms of the Rwandan state that allowed the rulers to absorb the most prosperous of their subjects into their own ranks through intermarriage, Tutsi too became an increasingly transethnic identity.

Further, Mahmood mentions that the predecessors of today's Hutu and Tutsi indeed created a single cultural community, the community of Kinyarwanda speakers, through centuries of cohabitation, intermarriage, and cultural exchange. In the course of history, Hutu and Tutsi emerged as 'state-enforced political identities'.

In this way, Mahmood discerns three phases in the development of the meaning of Hutu and Tutsi:

(a) In the distant past, Tutsi may have been an ethnic identity. Absorbing other groups into the Tutsi state, the others were identified as Hutu, a subject people, of trans-ethnic character.

(b) Tutsi accepted other elements into their dominant group. The term Tutsi is given a trans-ethnic character. Both Hutu and Tutsi emerged both as state-enforced political identities, and together they form a single cultural community. 
(c) In the colonial period, these political identities are considered as representing groups with different racial origins. Tutsi are seen as the intruders, 'born to rule', Hutu as the original population, destined to be subjected (Mamdani 2001: 73-5).

By the end of Rwabugiri's rule, the Hutu/Tutsi distinction clearly began to appear as a political distinction that divided the subject population from those identified as having power.

If Hutu/Tutsi evoked the subject/power distinction in the pre-colonial Rwandan state, the colonial state added a dimension to it: by racialising Hutu and Tutsi as identities, it signified the distinction as one between indigenous and alien.

Following Mamdani, we may conclude that the pre-colonial past was not characterised by social harmony, but by an increasing tension, not between races or tribes, but between leaders of a centralized hierarchical kingdom and servants at several levels. This development was continued in the colonial era, but was aggravated by its racialisation.

\section{The Conflict as a Regional Conflict within the Region of the Interlacustrine Area}

It is important to mention also Mamdani's explanation of the Rwanda conflict as a regional conflict in the interlacustrine area.

In Uganda by the end of the 1980s, President Museveni, re-examining the principle of ethnicity as a basis for Ugandan citizenship, was inclined to declare that ten years residency in the country could become a criterion for citizenship. It was thus to be made possible for Rwandan refugees, who were often in high positions, to become Ugandan citizens. At the end of the eighties, however, Museveni had to give in to strong opposition to these ideas. This made the Tutsi group, who were in a difficult position in Uganda, decide to use force to return to their home country, and to begin the Rwandan war in 1990 that culminated in the genocide in 1994.

A similar situation existed in Congo (Zaire). Several generations of former migrants from Rwanda had lived in a region near Mulenge, in the province of South-Kivu. Originally accepted as citizens of the State, by the end of the nineties, they were put in a difficult position as they were denied citizenship. Feeling stateless, they joined the Tutsi opposition (RPF) that had invaded Rwanda in 1990.

It is clear that this focus on the socio-political aspects of the Rwandan 
conflict does not change the problem of mutual hatred based on racism. This critical analysis, however, may stimulate discussion on the roots of the genocide in which also the political development of the Hutu-Tutsi relations may be taken into account, as well as questions of ethnicity and citizenship in the neighbouring countries.

\section{The Factor of Religion in the Political Conflict}

Looking back at the question asked at the beginning about the role of religion in the Rwandan genocide, we may conclude that the labelling of the antagonism between Tutsi and Hutu in Rwanda in terms of race, has been an important and decisive factor in the conflict. It fuelled the conflict between Hutu and Tutsi, and made the political conflict between rulers and servants that had existed by the end of the nineteenth century into something inevitable, a kind of fatality that had to be accepted. It changed the character of the distinction between the groups, and as a consequence ultimately created a dividing line between innate (Hutu) and non-native (Tutsi) groups. In moments of political tension, politicians have used this racist thinking to destroy their opponents.

The missionary movement, in which the Roman Catholic Church had a dominant position, has been most instrumental in promoting this way of thinking. The history of the genocide has shown that once thinking in racial terms is introduced, the Christian doctrine of the unity of the human species is unable to see it as a human construct.

The Christian Church still has to answer the question as to why the idea of the unity of mankind, a dominant element in the teaching of the Church through the ages, has not been powerful enough to unmask the ideological aspects of the Hamitic theory, which finds its origin in the conviction the European 'race' is superior.

The social revolution of 1959, in which the Hutu majority took over the ruling position of the Tutsi minority, was a change of political power. Tutsi who lost their position accused the Roman Catholic Church of taking sides with the Hutu against them, and, when they regained their leading position in Rwanda after the genocide, they would repay the Church for this. The accusation against the Catholic Church of having introduced divisive racist thinking into Rwanda has, therefore, to be seen in this political context.

The political ideal of the present government is to establish peaceful relations between all citizens in the future. This ideal of a peaceful society 
without racial distinctions is projected into the past. It is said, and believed, that in the glorious past of Rwanda the different social groups lived in peaceful harmony with each other. In doing so, full responsibility for the genocide is placed upon to the influence of the European colonisers who introduced divisions in order to rule, and underpinned their policy with racial theories.

The fact that this concept of Rwandan history is presented as the only legitimate view, gives it an ideological flavour. This ideological character of the interpretation of Rwandan history makes it impossible to speak freely about a growing antagonism between Hutu and Tutsi in the course of the nineteenth century. Those who blame the Europeans exclusively, in particular the Roman Catholic Church, for the genocide, are not prepared to take into account the divisions and antagonisms of the pre-colonial era.

This ideologically flavoured way of dealing with Rwandan's past precludes open discussion with those who have built the institutions of the First Republic under President George Kayibanda and of the Second Republic under President Juvénal Habyarimana. This lack of openness is a barrier to a national reconciliation between those who suffered under the political regime before independence and those who suffered under the political change after independence.

\section{Religious Change after the Genocide}

The strong criticism of the extremely powerful position of the Catholic Church in Rwandan society in the twentieth century also has had consequences for the religious landscape of the country after the genocide. It inspired the government after 1994 to give support to the proliferation of new Protestant Christian communities.

In the aftermath of the return of tens of thousands of Rwandan exiles from exile in neighbouring countries such as Uganda, Tanzania, Kenya, Congo (Zaire) and Burundi, many new independent churches were created.

For one or two generations, many of these exiles had lived in an English-speaking cultural context, and this made it difficult for them to join the existing churches in Rwanda. Some of the churches were originally prayer groups consisting of returned refugees which developed into larger organizations. In several cases, however, one may speak of the conscious foundation of church organizations, whose creation may be seen as a manifestation of the dissatisfaction of many people with the existing churches 
because of their assumed involvement in the genocide. The result is that for the first time in the history of the church in Rwanda, churches seem to be organised along ethnic lines.

One of the most outstanding communities in this category is the Restauration Church Association. It was founded by some pastors who returned from different countries and who had belonged to various denominations.

The church services started briefly after the genocide in the capital Kigali, in a purpose-built room which was offered by the local municipals. The denomination spread quickly throughout the country in urban centres where most of the newly arrived returnees had settled. According to the statement from its leaders, the main mission of the denomination is 'to reconcile Rwandans' or 'in collaboration with the government, reconstruct the country, which was destroyed by immoral men'. The words gusana imitima, that is 'to heal wounded hearts', are found in its logo. The denomination's services are mainly attended by those who work in shops, the offices of ministries, and banks, and by students.

Other churches have been introduced by returnees from different neighbouring countries. In 1994, David Ndahurutse, a former Rwandan refugee in Burundi, introduced the Eglise Vivante de Jésus Christ, which he had founded in 1992 in Burundi. Life Messengers in Mission (LMM), which has its origin in Kenya, was introduced in 1994 by returnees from Uganda. One of the fastest-growing churches is the Zion Temple, founded in the capital, shortly before 2000, by the self-styled Christian preacher Paul Gitwaza. ${ }^{4}$

In 1997, the number of these new Christian communities was estimated at about 150, whereas a few years later people spoke of more than 500 communities. This is even more noteworthy, if one takes into account the fact that African Independent Churches had never developed in Rwanda. ${ }^{5}$

4 For an initial attempt to research these new communities, see the report of CORVT, the Ecumenical Centre for Theological Research and Education (van 't Spijker 1998). CORVT is the abbreviation of the Centre oecuménique de recherche et de vulgarisation théologiques, the French name of the institute. The report gives an account of research into 22 different new Christian groups in Rwanda. See also, van't Spijker 1999.

5 David Barrett (1968) mentions only nine African states in which African independent churches were not to be found in 1967. Six of these states were predominantly Islamic. Rwanda was among the three others which had only churches founded by Western missionaries. 
Created after the 1994 genocide, and partly as a consequence of it, most of these churches uncritically condemn the Roman Catholic Church because of its assumed culpability for the genocide.

Whereas the political situation in post-war Rwanda has certainly contributed to the mushrooming of new Christian communities, other factors have contributed to this new phenomenon. Most of these new movements represent a spirituality that is not often found in the older, established churches that were the result of earlier European missionary activities. They are characterised by what in Rwanda is generally known as 'a Spirit of Pentecostalism', which is expressed in ecstatic prayer, baptism by immersion, testimonies of dreams and visions, and sometimes the experience of miraculous healing and glossolalia. Among these new Christian communities there are also neo-Pentecostal churches where women and young people play a prominent role, and where some form of prosperity Gospel is preached. In this respect, many of these churches represent a new wave of charismatic Christianity that has emerged everywhere in Africa in the last few decades.

\section{Growing Islam}

In speaking about religious change after the genocide, mention should also be made of the rise of Islamic influence in the country.

Islam has been present since 1899, when Muslim craftsmen entered the country in the service of German military units. At the same time, foreign traders originating from Asia also settled in the country. For almost a century, these Muslims lived on the margin of society, and only towards the end of the presidency of Juvénal Habyarimana, did the situation of Muslims improve. With the help of the Arab world several students were accepted at the University of Medina, and the Libyan President Muammar Gadaffi, was given the opportunity of building an impressive cultural centre in the capital, which began producing Muslim literature and a bulletin in the vernacular.

Among the returned exiles in 1994 there were numerous well-educated Muslims who are currently giving a new impulse to the Muslim community. Since 1994, the government has always counted several Muslims among its ministers. In the cities, one hears the call to prayer early in the morning. The end of Ramadan, Id-al-Fitr, has been a national holiday since 1995, whereas Ascension Day and Good Friday are no longer public holidays. 
Following a government statement, Muslims claim that there was no Muslim participation in the execution of the genocide. Christian leaders dispute this and there are also some Muslim leaders who admit that the claim is false. Nevertheless this argument is frequently used in public presentations.

This new position has given Muslims a new self-confidence. More people than ever wear Arab dress, not only in the cities, but also in rather remote areas. In some cases, the construction of mosques is strongly promoted by the local public or military authorities who themselves returned to the country after 1994 .

\section{Concluding Remarks}

The unprecedented disaster of war and genocide in Rwanda has deeply influenced and changed the religious landscape of Rwanda. The influence of the Roman Catholic Church has diminished considerably, in the aftermath of the negative assessment of its past by the present political leadership. To a certain degree the political shadow cast over the Catholic Church also affects the mainstream Protestant churches.

The negative reputation of the established churches has contributed to the tremendous growth of numerous new Christian communities.

Islam has become an important factor, growing both in numbers and influence.

Rwanda's past cannot be discussed openly in public, and the ambiguity towards it causes all aspects of the pattern to be open ended and reveals a feeling of uncertainty about the future.

\section{References}

\section{Barrett, David}

1968 Schism and Renewal in Africa. Nairobi: Oxford University Press.

Gatwa, Tharcisse

2005 The Churches and Ethnic Ideology in the Rwandan Crises 1900-1994. Bletchley: Regnum Books.

\section{Heremans, Roger}

1973 Introduction à la l'histoire au Rwanda. Bruxelles/Kigali: A. de Boeck / Editions rwandaises.

d'Hertefelt, Marcel

1971 Les clans du Rwanda ancien. Eléments d'ethnosociologie et d'ethnohistoire. Ter- 
vuren: Musée royal de l'Afrique Centrale Annales. (Série IN-8, Sciences humaines no. 70)

\section{Johanssen, Ernst}

1912 Ruanda. Kleine Anfäng - Grosse Aufgaben. Bethel: Verlangshandlung der Anstalt Bielefeld.

\section{Kagame, Paul}

2002 The Great Lakes Conflicts: Factors, Actors, and Challenges. An inaugural lecture delivered by His Excellency Paul Kagame, President of the Republic of Rwanda, at the Nigeria War College, Abuja, Nigeria, 16 September 2002. http: / / www.gov.rw/government/ president/ speeches / 2001/09_20_02_ abuja.html (accessed 24 October 2005).

\section{Kandt, Richard}

1919 Caput Nili. Eine empfindsame Reise zu den Quellen des Nils. Tome II. Berlin: Dietrich Reimer.

\section{Ki-Zerbo, Joseph}

1978 Histoire de l'Afrique noire. Paris: Hatier.

\section{Lemarchand, René}

1999 Ethnicity as Myth: the View from the Central Africa. Copenhagen: University of Copenhagen, Centre of African Studies. (Occasional Paper)

\section{Loupias, $\mathbf{P}$.}

1908 Tradition et légende des Patutsi sur la création du monde et leur établissement au Ruanda. Anthropos 3: 1-13.

\section{Mamdani, Mahmood}

2001 When Victims Become Killers. Colonialism, Nativism, and the Genocide in Rwanda. Princeton: Princeton University Press.

\section{Molenaar, Arthur}

2005 Gacaca: Grassroots Justice after Genocide. The Key to Reconciliation in Rwanda? Leiden: African Studies Centre. (Research Report, 77)

\section{Overdulve, C. M.}

1997 Rwanda. Un peuple avec une histoire. Paris: L'Harmattan.

Pagès, A.

1933 Un royaume Hamite au Centre d'Afrique. Bruxelles: Institut Royal Colonial Belge. (Collection IN-80, Tome I)

\section{Prunier, Gérard}

1995 The Rwanda Crisis 1959-1994: History of a Genocide. London: Hurst.

\section{Reyntjens, Filip}

1994 L'Afrique des grands lacs en crise. 1988-1994. Rwanda, Burundi: Paris: Karthala.

\section{Rutayisire, Antoine}

1996 Faith under Fire. Testimonies of Christian Bravery. London: African Enterprise.

\section{Sanders, Edith}

1969 The Hamitic hypothesis: its origin and function in time perspective. Journal of African History 10 (4): 521-32. 


\section{Spijker, Gerard van 't}

1997 The Churches and the Genocide in Rwanda. Exchange 26 (3): 233-54.

1998 Les communautés chrétiennes nouvelles au Rwanda. Rapport de recherches faites par les étudiants de la Faculté Théologie Protestante de Butare. Butare: Centre Ecuménique de Recherches et de Vulgarisation Théologiques.

1999 Religion in Rwanda after the Genocide. Studies in Interreligious Dialogue 9 (2): 156-77.

\section{Willame, Jean-Claude}

1995 Aux sources de l'hécatombe rwandaise. Brussels/Paris: Institut Africain CEDAF/L'Harmattan. (Les Cahiers Africains) 